\title{
Socjalne właściwości użytkowe budynków mieszkalnych w świetle badań ankietowych
}

\author{
Zygmunt Orlowski $^{1}$, Aleksandra Radziejowska ${ }^{2}$ \\ ${ }^{1}$ Katedra Geomechaniki, Budownictwa i Geotechniki, Wydziat Górnictwa i Geoinżynierii, AGH \\ Akademia Górniczo-Hutnicza im.A. MickiewiczawKrakowie, e-mail: orlowski@agh.edu.pl \\ ${ }^{2}$ Katedra Geomechaniki, Budownictwa i Geotechniki, Wydziat Górnictwa i Geoinżynierii, AGH \\ Akademia Górniczo-Hutnicza im. A. Mickiewiczaw Krakowie, e-mail: aradziej@agh.edu.pl
}

Streszczenie: W artykule autorzy rozpatrują jeden z aspektów zrównoważonego budownictwa - aspekt socjalny. Wśród aspektów społecznych, zgodnie z normą PN-EN 16309+A1:2014-12 wyróżniono następujące właściwości użytkowe budynku: dostępność, adaptowalność, komfort i zdrowie, wpływ sąsiedztwa, utrzymanie, bezpieczeństwo i ochronę. Autorzy przeprowadzili badania ankietowe wśród mieszkańców dzielnic Krakowa. W ankiecie uszczegółowiono pytania dotyczące właściwości użytkowych budynków. Badania miały na celu ustalić jak użytkownicy oceniają istotność badanych cech, które wpływają na funkcjonalność i komfort ich miejsca zamieszkania.

Słowa kluczowe: zrównoważony rozwój, aspekt socjalny, właściwości użytkowe, budynki mieszkalne, badania ankietowe.

\section{Wprowadzenie}

Zrównoważone budownictwo (Sustainability of Construction Works) zajmuje istotne miejsce $w$ działaniach zmierzających do realizacji założeń zrównoważonego rozwoju. Stosowanie zasad zrównoważonego rozwoju w budownictwie może zapewnić stałe polepszenie warunków życia ludzkości, większe bezpieczeństwo energetyczne oraz poprawę stanu środowiska naturalnego. Sektor budowlany stanowi podstawowy obszar działalności w gospodarkach wielu krajów w tym w gospodarce Unii Europejskiej. Jak zauważono w pracach [1] rozwiązywanie problemów budownictwa zrównoważonego ma charakter globalny. W krajach wspólnoty europejskiej budownictwo generuje około $10 \%$ PKB i zatrudnia $7 \%$ siły roboczej. Niestety, każda budowa, obiekt budowlany i jego użytkowanie powoduje wpływ na środowisko. Sektor budowlany przy obecnie stosowanych technologiach realizacji zadań budowlanych i sposobie ich eksploatacji stanowi istotne zagrożenie dla środowiska - jest przyczyną 42\% końcowego zużycia energii w UE, emisji 35\% gazów cieplarnianych do atmosfery, a także znacznego zużycia surowców nieodnawialnych takich jak woda czy surowce mineralne. Zagrożenie dla środowiska stanowią też pozostałości po rozbiórce obiektów budowlanych $[2,3,4]$. Niezbędna jest stała potrzeba kontynuowania i rozwijania kontaktów oraz wymiany doświadczeń między instytucjami naukowymi poszczególnych państw, a także przedsiębiorstwami wykonawczymi [1].

Przeciętny mieszkaniec naszej strefy klimatycznej spędza w mieszkaniu około $80 \%$ swojego życia. Jest oczywistym, że wewnętrzne środowisko i rozwiązania funkcjonalne w budynku mogą w sposób istotny wpływać na jakość życia użytkowników. Z tego też względu Komisja Europejska zainicjowała utworzenie Komitetu Technicznego CEN/TC 350 „Zrównoważone budownictwo”, który prowadzi prace nad normami związanymi ze 
zrównoważonym budownictwem [5, 6], w Polsce zaś powstał odpowiednik: Komitet PKNKT 307 [7].

Norma ISO 15392 Sustainability in building construction - General principles [8] wskazuje na ważność uwzględnienia trzech, wyżej wymienionych obszarów (aspektów) związanych z koncepcja zrównoważonego budownictwa.:

- aspekt środowiskowy,

- aspekt socjalny (społeczny),

- aspekt ekonomiczny.

W literaturze najczęściej wymienianymi aspektami są środowiskowy i ekonomiczny. Według wielu autorów priorytetem budownictwa zrównoważonego jest ograniczenie zużycia energii i zużywania zasobów naturalnych oraz ograniczenie produkcji odpadów i transportu. W niektórych publikacjach zrównoważone budownictwo jest kojarzone wyłącznie z budownictwem ekologicznym, ,zielonym”. W niniejszym artykule autorzy zajmują się aspektem społecznym, stosunkowo rzadko poruszanym w publikacjach, a mającym według autorów - największy wpływ na standard i komfort życia mieszkańców.

\section{Aspekt społeczny (socjalny) obiektu budowlanego}

W połowie 2014 roku została wprowadzona norma: PN-EN 16309:2014-05 - wersja angielska. Zrównoważoność obiektów budowlanych - Ocena socjalnych właściwości użytkowych budynków - Metodyka obliczania [9]. Norma ta zawiera metody i wymagania dotyczące oceny socjalnych właściwości użytkowych budynków z uwzględnieniem technicznych charakterystyk i funkcjonalności budynku. Poprzez ujednolicenie metod oceny stopnia zrównoważenia budynku w zakresie jego aspektów socjalnych, możliwe będzie przeprowadzenie porównań pomiędzy budynkami w różnych krajach (Unii Europejskiej). Norma PN-EN 16309:2014-05 znajduje zastosowanie we wszystkich typach budynków.

Wyróżniono w niej następujące kategorie socjalnych właściwości użytkowych budynku:

- dostępność,

- adaptowalność,

- komfort i zdrowie,

- wpływ sąsiedztwa,

- utrzymanie,

- bezpieczeństwo i ochrona.

Norma ta nie określa zasad oceny socjalnych właściwości użytkowych budynku, nie opisuje również poziomów, klas czy standardów funkcjonalności obiektu. Metody ocen, poziomy odniesienia, parametry budynków referencyjnych powinny być tworzone dla poszczególnych krajów oddzielnie [9]. Powinny one uwzględniać normy i rozporządzenia obowiązujące $\mathrm{w}$ danych krajach, strefy klimatyczne, przewidywane zmiany klimatu, stan środowiska, stan gospodarki, wielokulturowość społeczeństwa.

Aspekt socjalny - w kontekście zrównoważonego budownictwa - kładzie duży nacisk na jakość i komfort użytkowania obiektów, co wymaga prowadzenia badań w kierunku określenia oczekiwań mieszkańców co do miejsca ich zamieszkania. W związku z tym należy prowadzić badania wśród ekspertów i użytkowników mające na celu wskazanie najistotniejszych aspektów, które należy uwzględnić podczas projektowania obiektów, a także stopniowo wdrażać $\mathrm{w}$ trakcie prowadzenia prac remontowych i modernizacyjnych budynków mieszkalnych [10]. 


\section{Badania ankietowe}

W celu ustalenia wymagań użytkowników, poznania ważności czynników decydujących o socjalnych właściwościach obecnych miejsc zamieszkania, wśród mieszkańców wybranych osiedli mieszkaniowych Krakowa - Rys. 1 przeprowadzono badania ankietowe.

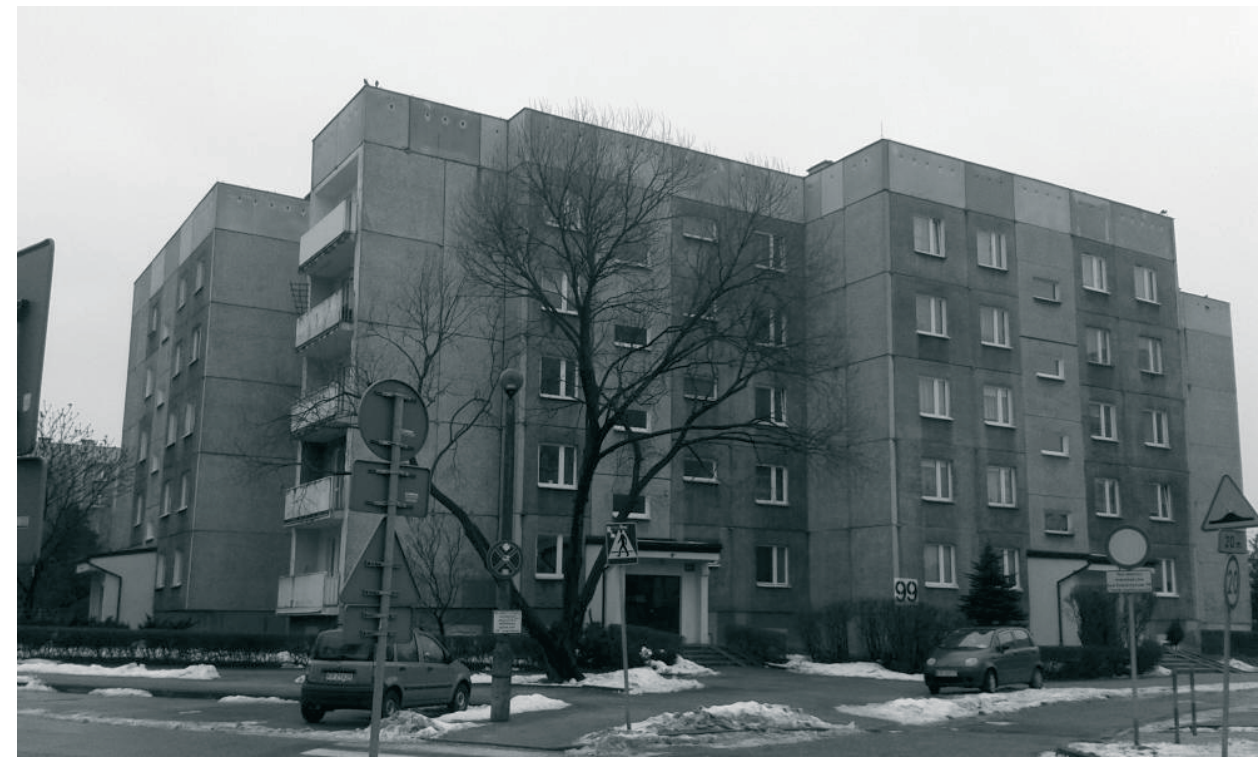

Rys. 1. Widok fragmentu osiedla mieszkalnego, gdzie przeprowadzono badania ankietowe

W ankiecie każda $\mathrm{z}$ właściwości użytkowych, wymienionych w punkcie 2, została uszczegółowiona - zakres ocenianych cech podano poniżej.

\section{a) Dostępność}

- Podejście do budynku z uwzględnieniem użytkowników o specjalnych potrzebach*

- Odległość od transportu publicznego (np. przystanek autobusowy)

- Odległość od parkingu

- Podjazd dla służb (np. straż pożarna, karetka itp.)

- Szerokie wejścia/wyjścia

- Łatwość otwierania wejść/wyjść (np. rozsuwane drzwi)

- Poręcze (np. przy wejściu do budynku)

- Szerokie korytarze

- Winda i odpowiednia jej wielkość

- Sterowanie ogrzewaniem, klimatyzacją i elektrycznością

- Media telekomunikacyjne (np. telefon, Internet, domofon itp.)

b) Adaptacyjność

- Możliwość łatwej zmiany układu pomieszczeń (np. likwidacja ścian działowych)

- Możliwość zmiany sposobu użytkowania (np. z mieszkalnego na lokal usługowy)

- Zdolność dostosowania budynku do indywidualnych wymagań użytkowników (np. dla ludzi poruszających się na wózkach)

- Wymiana urządzeń technicznych (np. urządzeń sanitarnych, ciepłowniczych itp.)

- Instalacja nowych urządzeń technicznych (np. windy) 
- Możliwość zainstalowania dodatkowych rur i kabli (np. systemy komunikacji, klimatyzacja)

- Ocieplenie budynku (w tym również od wewnątrz)

- Łatwość demontażu wewnętrznych urządzeń i elementów (np. zmiana szerokości schodów, w celu montażu windy)

c) Zdrowie i komfort użytkowania

- Komfort termiczny

- Wentylacja i klimatyzacja

- Izolacyjność akustyczna (słyszalność sąsiadów, hałas z zewnątrz)

- Akustyka przestrzenna (np. zbyt duży pogłos w pomieszczeniach)

- Zewnętrzny komfort wizualny (np. widok z okien)

- Komfort wizualny wewnątrz (np. wysokość pomieszczeń)

- Układ przestrzenny mieszkania (np. pokoje przejściowe)

- Odpowiednie oświetlenie zewnętrzne i wewnętrzne

d) Wpływ sąsiedztwa

- Hałas

- Emisja gazów na zewnątrz (np. spaliny z ogrzewania)

- Nocny blask (np. lampy na wprost okien)

- Dzienny blask (np. sąsiednie budynki odbijające światło)

- Przysłanianie (np. wysoko zabudowa w bliskim sąsiedztwie powodująca zacienienie)

- Odczuwalność wstrząsów/ wibracji (np. sąsiedztwo lokalu rozrywkowego, ruchliwej ulicy itp.)

e) Utrzymanie i konserwacja

- Łatwość w utrzymaniu budynku (np. łatwość utrzymania porządku na klatkach schodowych)

- Korzystanie z budynku podczas prac konserw. (np. czy wyst. duże niedogodności w użytkowaniu)

- Częstość i czas trwania konserwacji

- Bezpieczeństwo podczas prowadzenia prac konserwacyjnych (np. stosowanie folii podczas malowania klatki schodowej)

f) Ochrona i bezpieczeństwo

- Ochrona przed przerwami w dostawach mediów (np. dodatkowy agregat ciepła)

- Odporność na zmiany oddziaływań klimatycznych (np. intensywny deszcz, silny wiatr)

- Ochrona przeciw kataklizmom (np. powódź)

- Wyposażenie w systemy przeciwpożarowe i wyjścia ewakuacyjne

- Zabezpieczenia przed intruzami i wandalizmem [9].

Fragment omawianej ankiety przedstawiono na Rys. 2.

Respondenci mieli za zadanie ocenić istotność cech jakie wpływają / wpływałyby na komfort / funkcjonalność ich miejsca zamieszkania. Do oceny posłużyła skala punktowa od 0 do 10 . 
1. DOSTĘPNOŚĆ (ocena dostępu oraz możliwości korzystania z udogodnień)

Podejście do budynku z

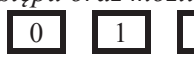

2
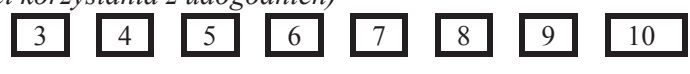

kowników o specjalnych potrzebach*

Odległość od transportu

publicznego (np. przysta-

nek autobusowy)

Odległość od parkingu

Podjazd dla służb ( $n p$.

straż pożarna, karetka

itp.)

Szerokie wejścia/wyjścia

Łatwość otwierania

wejść/wyjść (np. rozsu-
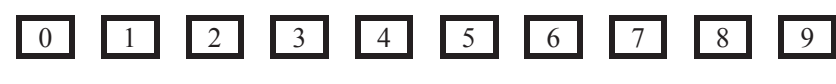

10
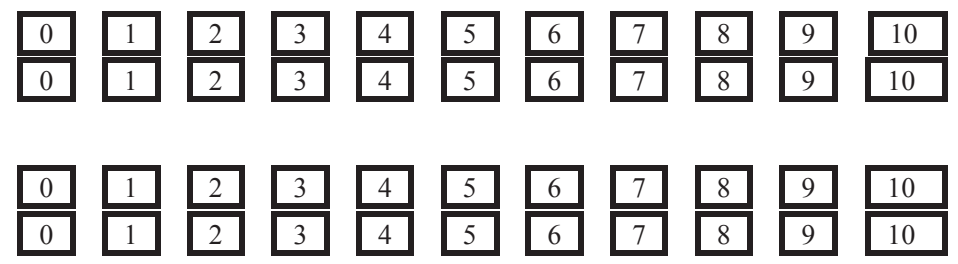

wane drzwi)

Poręcze (np. przy wejściu do budynku)
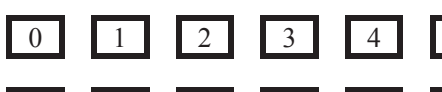

Szerokie korytarze

Winda i odpowiednia jej wielkość
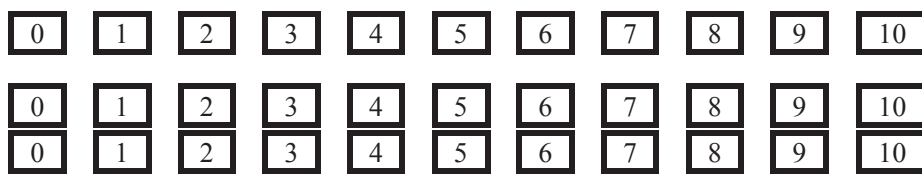

Sterowanie ogrzewaniem, klimatyzacją i elektrycznością

Media telekomunikacyjne (np. telefon, Internet,
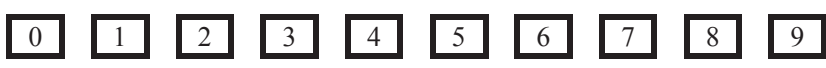

10 domofon itp.)

Rys. 2. Fragment przeprowadzanej ankiety wśród mieszkańców

\section{Zakończenie}

Z przeprowadzonych badań ankietowych wynika, że socjalne właściwości użytkowe budynków mieszkalnych mają istotne znaczenie w życiu ich użytkowników. Od stopnia spełnienia tych właściwości zależy, czy funkcjonowanie mieszkańców w danym obiekcie jest satysfakcjonujące, jest przyjazne, czy czują się w nim bezpiecznie, czy można mówić o komforcie zamieszkania [10].

Aspekt społeczny budownictwa zrównoważonego w sposób szczególny uwzględnia warunki funkcjonowania osób niepełnosprawnych, starszych, co w perspektywie przewidywanego starzenia się społeczeństwa ma istotne znaczenie.

Wyniki badań ankietowych wskazują, że socjalne właściwości użytkowe mogą wpływać również na działanie społeczne mieszkańców; następuje integracja między ludźmi, między mieszkańcami a budynkiem, a także między mieszkańcami a środowiskiem.

Podczas planowania robót remontowych i modernizacyjnych budynków mieszkalnych należy w ich zakresie uwzględnić oprócz podstawowych wymogów jakie powinien spełniać obiekt, w zakresie bezpieczeństwa, zawrzeć także wyniki badań ankietowych (opinię mieszkańców) dotyczących socjalnych właściwości użytkowych.

Praca wykonana $w$ ramach badań statutowych $n r$ 11.11.100.197 AGH Akademii Górniczo-Hutniczej w Krakowie. 


\title{
Literatura
}

1. Pabian A., Tomski P. Management in sustainable construction industry. Częstochowa University of Technology, Częstochowa, 2014.

2. Boczek Z. Budownictwo zrównoważone. Konferencja Infrastrukturalna MSZ, Warszawa, 20.05.2013, http://www.architektura.info (dostęp 03.11.2015).

3. Czarnecki L., Kaproń M. Definiowanie zrównoważonego budownictwa. Materiały Budowlane $1 / 2011$.

4. Czarnecki L., Kaproń M., Piasecki M., Wall S. Budownictwo zrównoważone budownictwem przyszłości. Inżynieria i Budownictwo 68(1) (2012).

5. ITB, Zrównoważone budownictwo. Warszawa: Seria Dokumenty Unii Europejskiej dotyczące budownictwa 21, Warszawa, 2010.

6. www.zb.itb.pl, (dostęp 02.11.2015)

7. Czarnecki L. M., Głowacz M. Działalność Komitetu Technicznego PKN-KT 307: Zrównoważone Budownictwo. Materiały Budowlane 2010.

8. ISO 15392: 2008, Sustainability in building construction - General principles.

9. PN-EN 16309+A1: 2014-12 (wersja angielska). Zrównoważoność obiektów budowlanych Ocena socjalnych wtaściwości użytkowych budynków - Metodyka obliczania.

10. Orłowski Z., Radziejowska A. Model for assessing the utility properties of a building, Conference People, Buildings And Environment, 10.2014, Kromeriz,

http://www.fce.vutbr.cz/ekr/pbe/Proceedings/2014/035_14164.pdf

\section{Social utility properties of residential buildings in the light of the survey}

\author{
Zygmunt Orłowski ${ }^{1}$, Aleksandra Radziejowska ${ }^{2}$
}

\author{
${ }^{1}$ Department of Geomechanics, Civil Engineering and Geotechnics, \\ Faculty of Mining and Geoengineering, AGH University of Science and Technology \\ name A. Mickiewicz in Cracow,e-mail: orlowski@agh.edu.pl \\ ${ }^{2}$ Department of Geomechanics, Civil Engineering and Geotechnics, \\ Faculty of Mining and Geoengineering, AGH University of Science and Technology \\ name A. Mickiewicz in Cracow, e-mail: aradziej@agh.edu.pl
}

Abstract: In the article, the authors consider one of the aspects of sustainable construction - the social aspect. Among the social aspects, in accordance with PN-EN $16309+$ A1: 2014-12 were listed the following utility properties of the building: accessibility, adaptability, comfort and health, neighborhood, maintenance, safety and security. The authors conducted a survey among the residents of Krakow districts. In the questionnaire were more detailed questions about the utility properties of buildings. Badania miały na celu ustalić jak użytkownicy oceniają istotność badanych cech, które wpływają na funkcjonalność i komfort ich miejsca zamieszkania. The study had be aimed at specify how users rate the importance of the studied traits that affect on the functionality and comfort of their domicile.

Keywords: sustainable development, social aspect, utility properties, residential buildings, surveys. 